\title{
Bacillus alveayuensis sp. nov., a thermophilic bacterium isolated from deep-sea sediments of the Ayu Trough
}

\author{
Seung Seob Bae, Jung-Hyun Lee and Sang-Jin Kim \\ Microbiology Laboratory, Korea Ocean Research and Development Institute, PO Box 29, \\ Ansan, 425-600, Republic of Korea
}

Correspondence

Sang-Jin Kim

s-jkim@kordi.re.kr
Thermophilic bacilli - aerobic or facultatively anaerobic, endospore-forming organisms - that grow optimally over the temperature range 45 to $<70{ }^{\circ} \mathrm{C}$ have been isolated from both thermophilic and mesophilic environments (Sharp et al., 1992). Several thermophilic bacilli have been isolated from ocean-bottom mud samples (Egorova, 1938), deep ocean-basin cores (Bartholomew \& Paik, 1966), shallow marine hot springs (Hjörleifsdóttir et al., 1989) and deep-sea hydrothermal vents (Marteinsson et al., 1995).

Currently, thermophilic bacilli are classified into seven genera: Bacillus, Brevibacillus (Sneath, 1986), Alicyclobacillus (Wisotzkey et al., 1992), Aneurinibacillus (Heyndrickx et al., 1997), Geobacillus (Nazina et al., 2001), Sulfobacillus (Dufresne et al., 1996) and Thermobacillus (Touzel et al., 2000). Molecular taxonomy shows that most of the thermophilic bacilli described to date belong to either

Published online ahead of print on 23 December 2004 as DOI 10.1099/ijs.0.63424-0.

The GenBank/EMBL/DDBJ accession numbers for the 16S rRNA gene sequences of strains $\mathrm{TM}^{\top}$ and TM5 are AY605232 and AY606801, respectively.

A table giving details of the cellular fatty acid compositions of strains $\mathrm{TM}^{\top}{ }^{\top}$ and TM5 and related thermophilic Bacillus species is available as supplementary material in IJSEM Online.
Bacillus rRNA group 1 or Bacillus rRNA group 5 (Ash et al., 1991; Rainey et al., 1994). Bacillus rRNA group 1 contains the thermophilic species Bacillus smithii and Bacillus coagulans, as well as their mesophilic relatives (Ash et al., 1991). Bacillus rRNA group 5 includes the genus Geobacillus and an aerobic, Gram-positive coccus, Saccharococcus thermophilus (Ash et al., 1991; Rainey et al., 1994; Nazina et al., 2001).

Gram characterization of the strains was done by using the Bio-Rad Gram staining kit according to the manufacturer's instructions. Morphologies of cells and spores were observed under a phase-contrast microscope (Zeiss Axioplan) at $1000 \times$ magnification. To enhance sporulation, cells were grown in marine broth 2216 (MB; Difco) containing $5 \mathrm{mg} \mathrm{MnSO}_{4} \mathrm{l}^{-1}$ at $55^{\circ} \mathrm{C}$ for 1 day. Catalase and oxidase activities were determined by bubble production in a $3 \%$ hydrogen peroxide solution and by oxidation of $1 \% p$-aminodimethylanine oxalate, respectively. Acid production from carbohydrates and other physiological tests were determined with the API 50CHB and API 20NE systems (bioMérieux), respectively, according to the manufacturer's instructions, with the exception that concentration of $\mathrm{NaCl}$ in the saline solution was $2 \cdot 0 \%(\mathrm{w} / \mathrm{v})$ instead of $0.5 \%$. To determine the optimal growth temperature, cells were tested at $30-70{ }^{\circ} \mathrm{C}$ in $\mathrm{MB}$; to test the optimal 
growth $\mathrm{pH}$, the distilled water in $\mathrm{MB}$ was replaced by the following buffers (Sigma) at a concentration of $20 \mathrm{mM}$ : for $\mathrm{pH} 4,5$ and 5.5, MES; for $\mathrm{pH} 6$ and 6.5, PIPES; for pH 7 and 7·5, HEPES; for $\mathrm{pH} \mathrm{8,} 9$ and 10, AMPSO. The requirement of $\mathrm{NaCl}$ was tested using modified $\mathrm{MB}$ (per litre distilled water: $5 \mathrm{~g}$ bactopeptone, $1 \mathrm{~g}$ yeast extract, $\left.0.01 \mathrm{~g} \mathrm{FePO}_{4} \cdot 4 \mathrm{H}_{2} \mathrm{O}\right)$ supplemented with different concentrations of $\mathrm{NaCl}$. Turbidity was monitored automatically by a temperature-gradient incubator (TVS126MA; Advantec) and the optimal temperature, $\mathrm{pH}$ and salinity were determined by calculating the growth rate in the exponential phase. Hydrolysis of casein, starch and tributyrin was tested as described by Marteinsson et al. (1996) and Scholz et al. (1987). To confirm anaerobic growth, cells were inoculated into MB medium in a serum vial capped with an aluminium seal and cultivated at $55^{\circ} \mathrm{C}$ for 7 days.

Genomic DNA was extracted from $1 \mathrm{ml}$ aliquots of cells of $\mathrm{TM}^{\mathrm{T}}$ and TM5 cultured in MB medium by using the Wizard genomic DNA purification kit (Promega). The 16S rRNA gene was amplified by PCR and purified as described by Sohn et al. (2004). The PCR products were sequenced by using a BigDye terminator cycle sequencing kit (Applied Biosystems) and an ABI PRISM 3100 Genetic Analyser (Applied Biosystems). The nearly complete (1500 nt) 16S rRNA gene sequences of the strains were used for phylogenetic analysis. Alignment gaps and unidentified base positions were not taken into consideration for the analysis. The 16S rRNA gene sequences of strains $\mathrm{TM}^{\mathrm{T}}$ and TM5 were compared with those in the GenBank database by using the BLAST algorithm (Altschul et al., 1990). Related sequences and the novel sequences were aligned by using CLUSTAL_X (Thompson et al., 1997), and the alignment was refined using PHYDIT (Chun, 1995) and manual comparison considering the secondary structures. The phylogenetic analysis was performed by using the computer packages PHYLIP (Felsenstein, 1993) and PAUP ${ }^{*} 4.0$ (Swofford, 1998). Phylogenetic trees were inferred using the FitchMargoliash (Fitch \& Margoliash, 1967), maximumlikelihood (Felsenstein, 1993), maximum-parsimony (Fitch, 1972) and neighbour-joining algorithms (Saitou \& Nei, 1987). Distance matrices for the neighbour-joining and Fitch-Margoliash methods were generated according to the model of Jukes \& Cantor (1969). The robustness of the topology in the phylogenetic trees was evaluated by bootstrap analyses (Felsenstein, 1985) of the neighbourjoining method based on 1000 resamplings.

Total lipids were extracted from cells that had been incubated at $55^{\circ} \mathrm{C}$ for 1 day by using the method of Folch et al. (1957). For analysis of the fatty acid composition, total lipids were converted to fatty acid methyl esters (FAMEs) by serial addition of $1.5 \% \mathrm{NaOH}$ and $5 \% \mathrm{HCl}$ in methanol; both reactions were repeated at $65^{\circ} \mathrm{C}$ for $20 \mathrm{~min}$. FAMEs were analysed as described by Sohn et al. (2004). The G $+\mathrm{C}$ content $(\mathrm{mol} \%)$ of strain $\mathrm{TM}^{\mathrm{T}}$ was determined by using the melting temperature method as described by Mandel et al. (1970) and Marmur \& Doty (1962). The melting temperature of purified chromosomal DNA extracted from Escherichia coli K-12 (KCTC 2443) was also determined, to serve as a control.

Strains $\mathrm{TM}^{\mathrm{T}}$ and TM5 had similar characteristics with respect to their cellular and colonial morphologies. Cells of both strains were Gram-positive, motile, rod-shaped $(0 \cdot 5-1 \cdot 0 \mu \mathrm{m}$ wide and $2 \cdot 5-5 \mu \mathrm{m}$ long) and occurred singularly or in chains. They produced ellipsoidal endospores that lay in terminal or subterminal positions and usually caused the sporangia to swell. Colonies that formed after 1 day incubation on marine agar 2216 (Difco) at $55^{\circ} \mathrm{C}$ were circular, opaque, cream and convex with entire margins. They did not grow under anaerobic conditions. Both strains grew between 40 and $65^{\circ} \mathrm{C}$, with optimum growth at $55^{\circ} \mathrm{C}$. The strains grew in the $\mathrm{pH}$ range $6 \cdot 5-9 \cdot 0$; the optimal growth $\mathrm{pH}$ was between $\mathrm{pH} 7 \cdot 0$ and $7 \cdot 5$. The $\mathrm{NaCl}$ concentration range for growth of strains $\mathrm{TM}^{\mathrm{T}}$ and TM5 was $0-4 \cdot 0 \%(\mathrm{w} / \mathrm{v})$, with the optimal concentration at 3.0 and $2.0 \%(\mathrm{w} / \mathrm{v})$, respectively. From tests done using the API 20NE system (bioMérieux), both strains gave positive results for aesculin hydrolysis ( $\beta$-glucosidase), acid production from glucose and assimilation of glucose, mannose and maltose, and negative results for oxidase, gelatin hydrolysis, reduction of nitrate to nitrite, reduction of nitrates to nitrogen, indole production, arginine dihydrolase, urease, $\beta$-galactosidase, utilization of citrate and assimilation of arabinose, mannitol, $\mathrm{N}$-acetylglucosamine, gluconate, caprate, adipate, malate, citrate and phenyl acetate. From tests done using the API 50CHB system (bioMérieux), acid production by both strains was positive for D-fructose, D-glucose, D-mannose, D-trehalose, maltose, sucrose, aesculin, 5-ketogluconate and glycerol, and negative for other substrates tested. Neither strain hydrolysed starch or tributyrin, but casein was hydrolysed by both strains. Physiological characteristics useful for differentiating between strains $\mathrm{TM}^{\mathrm{T}}$ and TM5 and related thermophilic Bacillus species are summarized in Table 1.

The 16S rRNA gene sequences of strains $\mathrm{TM}^{\mathrm{T}}$ and TM5 were continuous stretches of 1532 and $1530 \mathrm{nt}$, respectively. The level of $16 \mathrm{~S}$ rRNA gene sequence similarity between the two strains was $99 \cdot 8 \%$; hence, both strains should be assigned to a single taxon (Fig. 1). Based on $16 \mathrm{~S}$ rRNA gene sequence similarity data, it was found that the closest relatives of strain $\mathrm{TM}^{\mathrm{T}}$ were Bacillus aeolius DSM $15084^{\mathrm{T}}(96 \cdot 7 \%)$, B. smithii DSM $4216^{\mathrm{T}}(96 \cdot 1 \%)$, Bacillus methanolicus NCIMB $13113^{\mathrm{T}}(95 \cdot 8 \%)$ and Bacillus pallidus DSM $3670^{\mathrm{T}}(95 \cdot 7 \%)$. Sequence similarity of strain $\mathrm{TM}^{\mathrm{T}}$ with other Bacillus species with validly published names was less than $97 \%$. There are widely accepted criteria for delineating species in current bacteriology: these state that strains with DNA relatedness values of less than $70 \%$ or with more than $3 \%$ difference in their 16S rRNA gene sequences are considered to represent different species (Wayne et al., 1987).

The cellular fatty acids of strains $\mathrm{TM}^{\mathrm{T}}$ and TM5 ranged 
Table 1. Physiological characteristics of strains $T M 1^{\top}$ and $T M 5$ that differentiate them from related thermophilic Bacillus type strains

Strains: 1, TM1 ${ }^{\mathrm{T}}$; 2, TM5; 3, B. aeolius DSM $15084^{\mathrm{T}}$; 4, B. smithii DSM 4216 ${ }^{\mathrm{T}}$; 5, B. methanolicus NCIMB $13113^{\mathrm{T}}$; 6, B. pallidus DSM $3670^{\mathrm{T}}$. +, Positive; -, negative; d, variable; W, weak reaction; ND, not determined. All strains were positive for acid production from D-glucose, and negative for reduction of nitrate to nitrite and acid production from lactose.

\begin{tabular}{|c|c|c|c|c|c|c|}
\hline Characteristic & 1 & 2 & $3^{*}$ & $4 \dagger$ & $5 \ddagger$ & $6 \S$ \\
\hline \multicolumn{7}{|l|}{ Growth at: } \\
\hline $70{ }^{\circ} \mathrm{C}$ & - & - & - & - & - & + \\
\hline $65^{\circ} \mathrm{C}$ & + & + & + & + & - & + \\
\hline $25^{\circ} \mathrm{C}$ & - & - & - & + & - & - \\
\hline $\mathrm{pH} 8 \cdot 0$ & + & + & + & - & - & + \\
\hline \multicolumn{7}{|l|}{ Growth in the presence of: } \\
\hline $3 \% \mathrm{NaCl}$ & + & + & + & - & - & + \\
\hline $10 \% \mathrm{NaCl}$ & - & - & - & - & - & + \\
\hline Catalase & + & + & + & + & + & + \\
\hline Oxidase & - & - & + & + & + & + \\
\hline \multicolumn{7}{|l|}{ Hydrolysis of: } \\
\hline Aesculin & + & + & - & $\mathrm{d}$ & ND & $\mathrm{d}$ \\
\hline Casein & + & + & + & - & - & - \\
\hline Starch & - & - & + & $\mathrm{W}$ & - & $\mathrm{W}$ \\
\hline Tributyrin & - & - & ND & $\mathrm{ND}$ & $\mathrm{ND}$ & + \\
\hline Utilization of citrate & - & - & + & $\mathrm{d}$ & $\mathrm{ND}$ & - \\
\hline Anaerobic growth & - & - & - & + & - & - \\
\hline \multicolumn{7}{|l|}{ Acid from: } \\
\hline D-Fructose & + & + & + & + & - & + \\
\hline D-Galactose & - & - & - & $\mathrm{d}$ & - & - \\
\hline D-Mannose & + & + & + & $\mathrm{d}$ & $\mathrm{ND}$ & - \\
\hline D-Ribose & - & - & + & $\mathrm{d}$ & + & - \\
\hline D-Trehalose & + & + & + & + & - & $\mathrm{d}$ \\
\hline D-Xylose & - & - & + & $\mathrm{d}$ & - & - \\
\hline Cellobiose & - & - & + & $\mathrm{d}$ & - & - \\
\hline Maltose & + & + & + & $\mathrm{d}$ & + & $\mathrm{d}$ \\
\hline Rhamnose & - & - & - & $\mathrm{d}$ & ND & - \\
\hline Raffinose & - & - & + & - & + & $\mathrm{ND}$ \\
\hline Sucrose & + & + & + & - & - & + \\
\hline Glycogen & - & - & - & $\mathrm{d}$ & - & - \\
\hline Glycerol & + & $\mathrm{W}$ & + & $\mathrm{d}$ & - & ND \\
\hline Mannitol & - & - & + & $\mathrm{d}$ & + & - \\
\hline Sorbitol & - & - & - & $\mathrm{d}$ & + & ND \\
\hline 5-Ketogluconate & + & + & + & - & ND & ND \\
\hline DNA G $+C$ content $(\mathrm{mol} \%)$ & $38 \cdot 7$ & $\mathrm{ND}$ & $40 \cdot 8$ & $38 \cdot 2-41 \cdot 7$ & $48-50$ & $39-41$ \\
\hline
\end{tabular}

${ }^{\star}$ Data from Gugliandolo et al. (2003).

$\dagger$ Data from Nakamura et al. (1988).

$\ddagger$ Data from Arfman et al. (1992).

\$Data from Scholz et al. (1987).

from $\mathrm{C}_{12}$ to $\mathrm{C}_{18}$ and included saturated, monoenoic and iso-branched components. In both strains, iso- $\mathrm{C}_{15: 0}$, iso$\mathrm{C}_{16: 0}, \mathrm{C}_{16: 0}$, iso- $\mathrm{C}_{17: 0}$ and anteiso- $\mathrm{C}_{17: 0}$ were the major fatty acids. A comparison of cellular fatty acid compositions of strains $\mathrm{TM}^{\mathrm{T}}$ and TM5 and related thermophilic Bacillus species is given in a Supplementary Table in IJSEM Online.
The DNA G + C content of strain $\mathrm{TM}^{\mathrm{T}}$ was $38.7 \mathrm{~mol} \%$. On the basis of the above-mentioned phenotypic and genetic characteristics of strains $\mathrm{TM}^{\mathrm{T}}$ and $\mathrm{TM} 5$, we consider the two strains to be distinct from other Bacillus species and propose that they are assigned to a novel species, Bacillus alveayuensis sp. nov. 


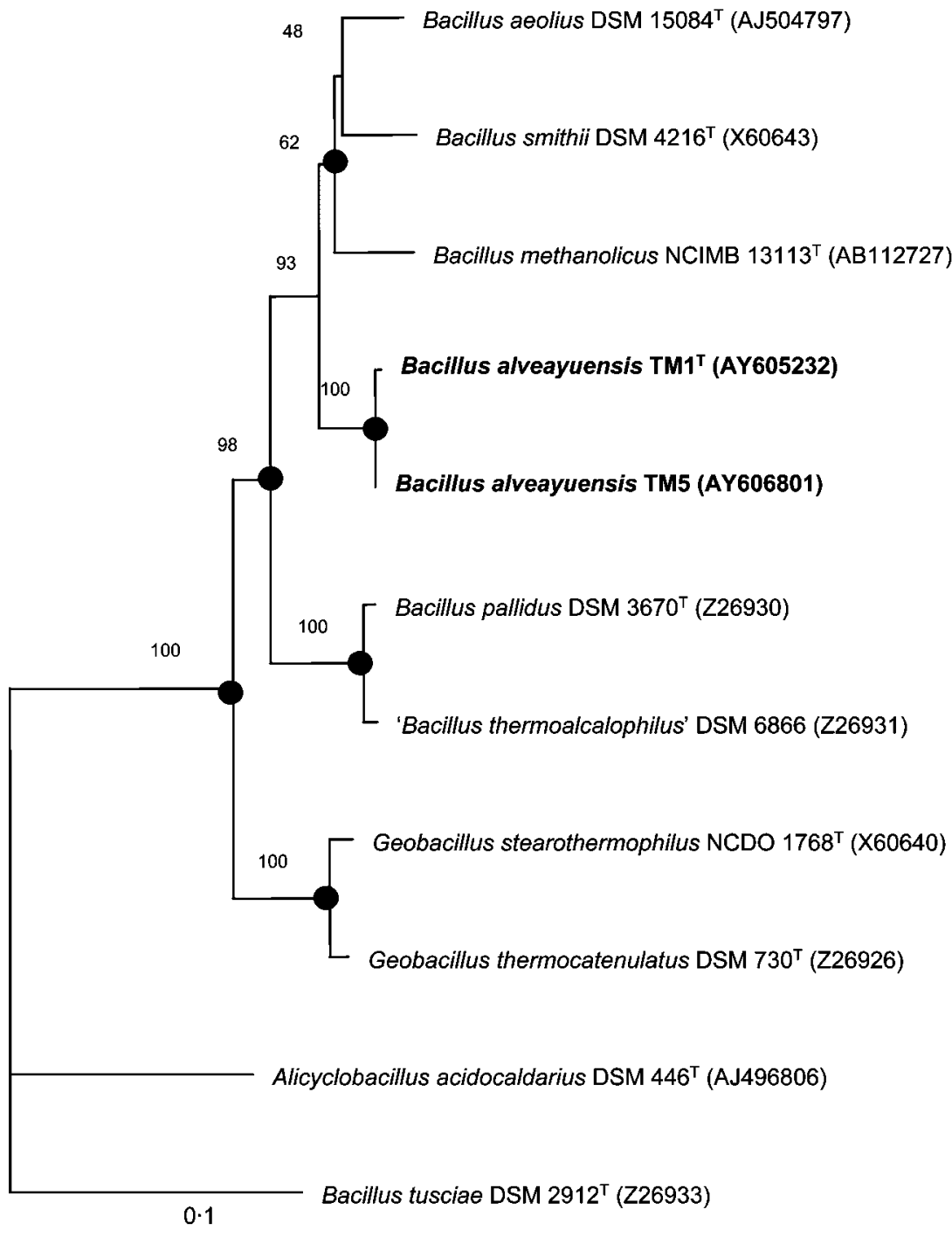

Fig. 1. Neighbour-joining tree based on nearly complete $16 \mathrm{~S}$ rRNA gene sequences, showing relationships between strains $\mathrm{TM}^{\top}$ and TM5 and some closely related taxa of the family Bacillaceae. Bootstrap percentage values based on neighbour-joining analyses of 1000 replications have been included at nodes, and solid circles indicate that the corresponding nodes (groupings) are also recovered in Fitch-Margoliash, maximumparsimony and maximum-likelihood trees. Bar, $0 \cdot 1$ nucleotide substitution per position.

\section{Description of Bacillus alveayuensis sp. nov.}

Bacillus alveayuensis [al.ve.a.yu.en'sis. L. n. alveus trough; N.L. masc. adj. ayuensis pertaining to Ayu (as a locality); N.L. masc. adj. alveayuensis pertaining to the Ayu Trough in the Pacific Ocean].

Cells are Gram-positive, rod-shaped $(0 \cdot 5-1 \cdot 0 \mu \mathrm{m}$ wide and $2 \cdot 5-5 \mu \mathrm{m}$ long), motile and occur singularly or in chains. They produce ellipsoidal endospores that lie in terminal or subterminal positions and usually cause the sporangia to swell. Colonies that form after 1 day incubation on marine agar 2216 at $55^{\circ} \mathrm{C}$ are circular, opaque and cream. Obligate aerobe. Grows optimally at $55^{\circ} \mathrm{C}, \mathrm{pH} 7 \cdot 0$ $7 \cdot 5$ and $3.0 \% \mathrm{NaCl}$. Does not grow in marine broth 2216 below $40{ }^{\circ} \mathrm{C}$ or higher than $65^{\circ} \mathrm{C}$ and $4.0 \% \mathrm{NaCl}$. Data on the utilization of carbon sources and on the hydrolysis of chromogenic substrates are shown in Table 1 . The major fatty acids are 13-methyl tetradecanoic acid (iso- $\mathrm{C}_{15: 0}$ ), 14-methyl pentadecanoic acid (iso- $\mathrm{C}_{16: 0}$ ), hexadecanoic acid $\left(\mathrm{C}_{16: 0}\right)$, 15-methyl hexadecanoic acid (iso- $\left.\mathrm{C}_{17: 0}\right)$ and 14-methyl hexadecanoic acid (anteiso- $\mathrm{C}_{17: 0}$ ).

The type strain $\left(\mathrm{TM} 1^{\mathrm{T}}=\mathrm{KCTC} 10634^{\mathrm{T}}=\mathrm{JCM} 12523^{\mathrm{T}}\right)$ and a reference strain (TM5) were isolated from deep-sea sediment of the Ayu Trough (4000 m below sea level) in the western Pacific Ocean. The DNA G + C content of the type strain is $38.7 \mathrm{~mol} \%$.

\section{Acknowledgements}

We thank the chief scientist of the DAE-YANG cruise (2001), Dr S. M. Lee, and the captain and crew of the RV ONRURI. We also thank Dr H. J. Seo, K. K. Kwon, J. H. Kang and Y. J. Kim for technical assistance, and give special thanks to Professor Dr H. G. Trüper for help with the Latin nomenclature. This work was supported by the $21 \mathrm{C}$ Frontier Microbial Genomics and Applications Center Program, Ministry of Sciences \& Technology (Grant MG 02-0101-001-1-0-0), the Marine Novel Bioactive Development Program, Ministry of Marine Affairs and Fisheries, and the in-house project (PE87200) of KORDI, Republic of Korea. 


\section{References}

Altschul, S. F., Gish, W., Miller, W., Myers, E. W. \& Lipman, D. J. (1990). Basic local alignment search tool. J Mol Biol 215, 403-410.

Andersson, M., Laukkanen, M., Nurmiaho-Lassila, E.-L., Rainey, F. A., Niemelä, S. I. \& Salkinoja-Salonen, M. (1995). Bacillus thermosphaericus sp. nov., a new thermophilic ureolytic Bacillus isolated from air. Syst Appl Microbiol 18, 203-220.

Arfman, N., Dijkhuizen, L., Kirchhof, G. \& 8 other authors (1992). Bacillus methanolicus sp. nov., a new species of thermotolerant, methanol-utilizing, endospore-forming bacteria. Int J Syst Bacteriol 42, 439-445.

Ash, C., Farrow, J. A. E., Wallbanks, S. \& Collins, M. D. (1991). Phylogenetic heterogeneity of the genus Bacillus revealed by comparative analysis of small-subunit-ribosomal RNA sequences. Lett Appl Microbiol 13, 202-206.

Bartholomew, J. W. \& Paik, G. (1966). Isolation and identification of obligate thermophilic sporeforming bacilli from ocean basin cores. J Bacteriol 92, 635-638.

Chun, J. (1995). Computer-assisted classification and identification of actinomycetes. $\mathrm{PhD}$ thesis, University of Newcastle, Newcastle upon Tyne, UK.

Dufresne, S., Bousquest, J., Boissinot, M. \& Guay, R. (1996) Sulfobacillus disulfidooxidans sp. nov., a new acidophilic, disulfideoxidizing, Gram-positive, spore-forming bacterium. Int $J$ Syst Bacteriol 46, 1056-1064.

Egorova, A. A. (1938). Thermophilic bacteria in arctic areas. $C R$ (Doki) Acad Sci U S S R 19, 649-650.

Felsenstein, J. (1985). Confidence limits on phylogenies: an approach using the bootstrap. Evolution 39, 783-791.

Felsenstein, J. (1993). PHYLIP (phylogeny inference package), version 3.5c. Department of Genetics, University of Washington, Seattle, USA.

Fitch, W. M. (1972). Toward defining the course of evolution: minimum change for a specific tree topology. Syst Zool 20, 406-416.

Fitch, W. M. \& Margoliash, E. (1967). Construction of phylogenetic trees. Science 155, 279-284.

Folch, J., Lees, M. \& Sloane Stanley, G. H. (1957). A simple method for the isolation and purification of total lipids from animal tissues. J Biol Chem 226, 497-509.

Gugliandolo, C., Maugeri, T. L., Caccamo, D. \& Stackebrandt, E. (2003). Bacillus aeolius sp. nov. a novel thermophilic, halophilic marine Bacillus species from Eolian Islands (Italy). Syst Appl Microbiol 26, 172-176.

Heyndrickx, M., Lebbe, L., Vancanneyt, M. \& 7 other authors (1997). A polyphasic reassessment of the genus Aneurinibacillus, reclassification of Bacillus thermoaerophilus (Meier-Stauffer et al. 1996) as Aneurinibacillus thermoaerophilus comb. nov., and emended descriptions of A. aneurinilyticus corrig., and A. migulans, and A. thermoaerophilus. Int J Syst Bacteriol 47, 808-817.

Hjörleifsdóttir, S., Kristjánsson, J. K. \& Alfredsson, G. A. (1989). Thermophilic organisms in submarine freshwater hot springs in Iceland. In Microbiology of Extreme Environments and its Potential for Biotechnology, pp. 109-112. Edited by M. S. Da Costa, J. C. Duarte \& R. A. D. Williams. London: Elsevier.

Jukes, T. H. \& Cantor, C. R. (1969). Evolution of protein molecules. In Mammalian Protein Metabolism, vol. 3, pp. 21-132. Edited by H. N. Munro. New York: Academic Press.

Mandel, M., Igambi, L., Bergendahl, J., Dodson, M. L., Jr \& Scheltgen, E. (1970). Correlation of melting temperature and caesium chloride buoyant density of bacterial deoxyribonucleic acid. J Bacteriol 101, 333-338.
Marmur, J. \& Doty, P. (1962). Determination of the base composition of deoxyribonucleic acid from its thermal denaturation temperature. J Mol Biol 5, 109-118.

Marteinsson, V. Th., Birrien, J.-L., Kistjánsson, J. K. \& Prieur, D. (1995). First isolation of thermophilic non-sporulating heterotrophic bacteria from deep-sea hydrothermal vents. FEMS Microbiol Ecol 18, 163-174.

Marteinsson, V. Th., Birrien, J. L., Jeanthon, C. \& Prieur, D. (1996). Numerical taxonomic study of thermophilic Bacillus isolated from three geographically separated deep-sea hydrothermal vents. FEMS Microbiol Ecol 21, 255-266.

Nakamura, L. K., Blumenstock, I. \& Claus, D. (1988). Taxonomic study of Bacillus coagulans Hammer 1915 with a proposal for Bacillus smithii sp. nov. Int J Syst Bacteriol 38, 63-73.

Nazina, T. N., Tourova, T. P., Poltaraus, A. B. \& 8 other authors (2001). Taxonomic study of aerobic thermophilic bacilli: descriptions of Geobacillus subterraneus gen. nov., sp. nov. and Geobacillus uzenensis sp. nov. from petroleum reservoirs and transfer of Bacillus stearothermophilus, Bacillus thermocatenulatus, Bacillus thermoleovorans, Bacillus kaustophilus, Bacillus thermoglucosidasius and Bacillus thermodenitrificans to Geobacillus as the new combinations G. stearothermophilus, G. thermocatenulatus, G. thermoleovorans, G. kaustophilus, G. thermoglucosidasius and G. thermodenitrificans. Int J Syst Evol Microbiol 51, 433-446.

Rainey, F. A., Fritze, D. \& Stackebrandt, E. (1994). The phylogenetic diversity of thermophilic members of the genus Bacillus as revealed by $16 \mathrm{~S}$ rDNA analysis. FEMS Microbiol Lett 115, 205-211.

Saitou, N. \& Nei, M. (1987). The neighbor-joining method: a new method for reconstructing phylogenetic trees. Mol Biol Evol 4, 406-425.

Scholz, T., Demharter, W., Hensel, R. \& Kandler, O. (1987). Bacillus pallidus sp. nov., a new thermophilic species from sewage. Syst Appl Microbiol 9, 91-96.

Sharp, R. J., Riley, P. W. \& White, D. (1992). Heterotrophic thermophilic bacilli. In Thermophilic Bacteria, pp. 19-50. Edited by J. K. Kristjansson. Boca Raton: CRC Press.

Sneath, P. H. A. (1986). Endospore-forming Gram-positive rods and cocci. In Bergey's Manual of Systematic Bacteriology, vol. 2, pp. 11041207. Edited by P. H. A. Sneath, N. S. Mair, M. E. Sharpe \& J. G. Holt. Baltimore: William \& Wilkins.

Sohn, J. H., Kwon, K. Y., Kang, J.-H., Jung, H. B. \& Kim, S.-J. (2004). Novosphingobium pentaromativorans sp. nov., a high-molecular-mass polycyclic aromatic hydrocarbon-degrading bacterium isolated from estuarine sediment. Int J Syst Evol Microbiol 54, 1483-1487.

Swofford, D. L. (1998). PAUP* - Phylogenetic Analysis Using Parsimony ( ${ }^{*}$ and other methods), version 4.0. Sunderland, MA: Sinauer Associates.

Thompson, J. D., Gibson, T. J., Plewniak, F., Jeanmougin, F. \& Higgins, D. G. (1997). The CLUSTAL_X windows interface: flexible strategies for multiple sequence alignment aided by quality analysis tools. Nucleic Acids Res 25, 4876-4882.

Touzel, J. P., O'Donohue, M., Debeire, P., Samain, E. \& Breton, C. (2000). Thermobacillus xylanilyticus gen. nov., sp. nov., a new aerobic thermophilic xylan-degrading bacterium isolated from farm soil. Int J Syst Evol Microbiol 50, 315-320.

Wayne, L. G., Brenner, D. J., Colwell, R. R. \& 9 other authors (1987). International Committee on Systematic Bacteriology. Report of the ad hoc committee on reconciliation of approaches to bacterial systematics. Int J Syst Bacteriol 37, 463-464.

Wisotzkey, J. D., Jurshuk, P., Jr, Fox, G. E., Deinhard, G. \& Poralla, K. (1992). Comparative sequence analyses on the 16S rRNA (rDNA) of Bacillus acidocaldarius, Bacillus acidoterrestris, and Bacillus cycloheptanicus and proposal for creation of a new genus, Alicyclobacillus gen. nov. Int J Syst Bacteriol 42, 263-269. 